\title{
Method of Text Content Development in Creation of Professionally Oriented Online Courses for Oil and Gas Specialists
}

\author{
https://doi.org/10.3991/ijet.v14i17.10747 \\ Yuliya Murzo ${ }^{(凶)}$, Svetlana Sveshnikova, Natalia Chuvileva \\ Saint-Petersburg Mining University, Saint-Petersburg, Russia \\ Murzo_YuE@pers.spmi.ru
}

\begin{abstract}
The article analyzes the experience of text content development for an online course created for oil and gas professionals. The article features a critical review of the current situation in online systems of distance learning, establishes principles of creating professionally oriented language curricula, as well as requirements to the functionality of online platforms that enable creation of such courses and their delivery to the audience. The work provides a detailed analysis of text content development principles and criteria. It presents three stages of developing text content for the first module of a professionally oriented online course.
\end{abstract}

Keywords-Distance learning, online course, professionally oriented education, professional production terminology, interindustry terminology, terminological system

\section{Introduction}

Since the onset of distance learning in 1960s in the University of Illinois, USA, this progressive learning method experienced a rapid take off to the first official online course in 1986 (for MS DOS computers). At the same time, interactive courses gained their momentum. In 2002, the Massachusetts Institute of Technology provided free access to its online courses. By 2009, about 5.5 million students were participating in at least one online course, and today two in every three students in the whole world participate in at least one online course [1] [2]. Online learning is one of the kinds of e-learning used for description of cognitive theory of learning via multimedia [3] [4] Online courses can be synchronous or asynchronous depending on the tasks set out by the course creator. From the point of view of creation and support of professionally oriented foreign language course, asynchronous interaction with learners is more flexible [5]. In online learning, a combined network approach is also possible [6].

Online courses are focused on information technologies in learning - for interaction with the teacher and between students and for access to learning materials (texts, audio, video) and tests [7]. The most popular way to develop and deliver online courses 
to learners is through special learning platforms with online courses on many subjects available.

This article considers some aspects of creating a curriculum for a language course ("Professionally oriented English language for Oil and Gas Professionals"). Curricula of such courses should include the following learning materials and activities:

- Professionally oriented texts with activities and comprehension tasks

- Professionally oriented audio/video materials with activities and comprehension tasks

- Grammar materials and activities

- Case webinars

- Progress tests

- Final certification test for the entire course

Usually the learning platforms provide the necessary functions for creation of highquality online courses. The following platform options are compulsory:

- Create author courses

- Publish texts, learning, audio/video materials, grammar and vocabulary activities

- Publish progress and achievement tests and arrange feedback from learners

- Provide separate access for teachers and learners to an online course

Besides, the following platform options would be advisable for providing interaction with learners like conducting of webinars and video conferences, subscription management, online payment systems, connection with CRM system.

In general, according to the authors, development of professionally oriented online language courses should meet the following requirements:

- Well-defined aims

- Detailed curriculum

- Thorough analysis of selected texts and audio/video materials (they need to be authentic, professionally up-to-date and contain the necessary set of grammatical and lexical aspects that are the subject of the course curriculum)

- Development of a set of activities

- Compiling progress and achievement tests

While working on the English online course for professionals, the authors faced some difficulties in selecting of authentic texts and audio/video materials. It was decided to develop their own text content that would meet a number of requirements that will be thoroughly analyzed in the following sections.

\section{Materials and Methods}

Creating the English online course for oil and gas professionals was aimed at development of text content that would become the basis of expertise necessary for carrying out a number of professional activities successfully. The use of authentic mate- 
rials traditional for ESL teaching practice in Russia was not advisable due to possible copyright violation. Besides, even high-quality authentic materials could be not relevant for the whole set of problems to be solved during the development of learning materials. So, the authors faced the task of creating their own text content for different modules of the online course that could be interesting for the target audience.

It was decided to use the same principles for developing texts as for selecting authentic texts for professionally oriented ESL teaching [9]. One of the main principles was to meet the professional interests of potential learners. The target audience of the developed online course were oil and gas professionals with command of English at A2/B1 level. They did not have constant language practice, but they felt the need to revise the previously studied grammatical and lexical material, learn to read and understand professional literature in English and develop communication skills to interact with foreign colleagues. Texts and activities of the online course should be interesting for this audience, so that the learners had fun in the process expanding their knowledge and learning something new. It was very important, therefore, to focus on innovations in the oil and gas sphere and also on the analysis of history and current trends in this sphere.

Textual material was not only to be up-to-date and informative, but also understandable for the learners. Texts that were too difficult might make learners' motivation lower. It was important to determine the optimal volume of textual material and the level of language difficulty for every online course module. Considering the necessity to include before-you-read, while-you-read and after-you-read activities in the online course, the authors decided to limit the text content by 2000-2500 symbols including spaces. The set of activities was aimed at developing learners' skills of written and spoken communication on a number of professional topics, so the content of textual material should correspond to the principle of communicative directivity, meaning that the texts were to show functions of certain language items, ensure understanding of their meanings and show how they are used in real speech. According to L. Bolsunovskaya, it is important to draw special attention of learners to the differences between printed texts and e-texts so that they could communicate with their colleagues successfully [10].

Another important principle was consistency in developing language skills. In the first module of the online course there should be simple well-known grammar structures and vocabulary items with subsequent gradual increase in complexity and numbers of new English terms and constructions. Selection of grammar structures to be revised did not pose a difficulty to the authors. For learners with command of English at A2/B1 level the following grammar structures were selected:

- Narrative tenses for speaking about the history of the professional field

- Present simple, present continuous and present perfect tenses for analysis of current tendencies

- Future simple and 'be going to' for predictions

- Passive voice to describe various kinds of equipment and technological processes

- Countable and uncountable nouns, the singular and plural of countable nouns, subject-verb agreement 
- Comparatives and superlatives of adjectives and adverbs

The consistency principle was followed in selecting vocabulary items that would be necessary for a successful professional communication. Vocabulary items that were to be included in the textual material of the online course were selected as a result of thorough frequency analysis of various authentic technical texts of appropriate topics.

With those principles in mind, the following rules were established for developing texts and sets of activities:

- The content should fit the topic

- It should be useful and informative

- It should match the level of professional expertise and language command of learners

- It should include the selected grammar structures

- It should include a certain number of professional vocabulary items and the previously introduced lexical material has to be revised in the second and subsequent modules of the online course

In the next section, the process of the text content development is described and analyzed according to these criteria.

\section{$3 \quad$ Results}

Developing the textual material, the authors assumed that the content of the English online course for oil and gas professionals was one of the key features that made it interesting and engaging for learners. To create of a high-quality material that met the aims of the online course was quite difficult for two main reasons:

- It was not an easy task to choose an ideal text due to a great variety of information existing on the subject

- The text had to include lexical and grammatical material that would correspond to the aims of the online course (considering the lexical peculiarities of professionally oriented texts for oil and gas industry and a lot of loan terms from other languages) [11].

In the modern world when people are overloaded with information, when the Internet gives thousands of answers to any single question, it is hard to create something truly engaging. Selection of really interesting facts and meaningful concepts became an important task of the first stage of the text content development. It required a thorough analysis of Russian and foreign Internet sources about the history of petroleum industry. Based on the selected information, interesting actual data on this subject were presented in the chronological order (Table 1). 
Table 1. Timeline of Oil History

\begin{tabular}{|c|c|}
\hline No & $\begin{array}{l}\text { Historical Facts } \\
\end{array}$ \\
\hline 1 & $\begin{array}{l}\text { In its early beginnings, oil was used by the Indus community of Mehrgarh to waterproof crop } \\
\text { baskets, by the Ancient Egyptians in their mummification processes, by the Babylonians to build } \\
\text { roads and architecture [12]. }\end{array}$ \\
\hline 2 & Liquid oil was first used as a medicine by the ancient Egyptians. \\
\hline 3 & $\begin{array}{l}\text { The Assyrians used bitumen as a means of punishment by pouring it over the heads of lawbreak- } \\
\text { ers. }\end{array}$ \\
\hline 4 & $\begin{array}{l}\text { The Persians used incendiary arrows wrapped in oil-soaked fibres at the siege of Athens in } 480 \\
\text { BC. }\end{array}$ \\
\hline 5 & $\begin{array}{l}\text { Early in the Common Era the Arabs and Persians distilled crude oil to obtain flammable products } \\
\text { for military purposes. [13] }\end{array}$ \\
\hline 6 & $\begin{array}{l}\text { Oil seeps were plentiful in North America. American Indians were reported to have used the oil } \\
\text { for medicinal purposes. }\end{array}$ \\
\hline 7 & $\begin{array}{l}\text { In the United States, circa Revolutionary War era, Native Americans taught George Washington } \\
\text { how to use oil to treat frostbite. [12] }\end{array}$ \\
\hline 8 & $\begin{array}{l}\text { China around } 347 \mathrm{AD} \text {, with depths of up to } 240 \mathrm{~m}(\sim 800 \mathrm{ft}) \text {. } \\
\text { basic drill-bits attached to bamboo poles. }\end{array}$ \\
\hline 9 & $\begin{array}{l}\text { Chinese engineers used bamboo pipelines to drill } 240 \text { meters below the surface to extract the } \\
\text { earliest drops of oil. Back then, oil was known as "burning water" and was used to evaporate brine } \\
\text { and produce salt. [14] }\end{array}$ \\
\hline 10 & $\begin{array}{l}\text { nued until the 10th century, by which time extensive bamboo pipelines } \\
\text { ith salt springs. }\end{array}$ \\
\hline 11 & $\begin{array}{l}\text { Also, during the 10th Century, al-Mas'udi, an Arabic geographer, observed oil seeps in Sicily, } \\
\text { Oman, Yemen, Iraq, Iran, Turkmenistan, Tashkent, India, Sumatra, and Azerbaijan. He called the } \\
\text { Absheron peninsular in modern Azerbaijan bilad al-naffata (the land of the naphtha fountain). By } \\
\text { this time, it is estimated that 10,000-15,000 people lived in and around Baku, almost of all of } \\
\text { whom would have been involved in the industry of extraction of oil and its transportation by ship, } \\
\text { cart, or camel. Extraction methods in those times were extremely primitive - mainly hand dug } \\
\text { wells at natural seep locations taken to a very shallow depth. [15] }\end{array}$ \\
\hline 12 & $\begin{array}{l}\text { iry A.D. they dug oil wells near Baku, scooped the thick black } \\
\text { and filled wineskins with it. Then, together with other goods car- } \\
\text { it to Persia, Mesopotamia and India. }\end{array}$ \\
\hline 13 & $\begin{array}{l}\text { In Russia, the first written mention of the gathering of oil appeared in the 16th century. Travelers } \\
\text { described how tribes living along the banks of the river Ukhta gathered oil from the surface of the } \\
\text { river and used it as a medicine and a lubricant. [16] }\end{array}$ \\
\hline 14 & $\begin{array}{l}\text { drilled at Bibi-Aybat near Baku in 1848, more than a decade } \\
\text { in the US. }\end{array}$ \\
\hline 15 & $\begin{array}{l}\text { In } 1848 \mathrm{~F} \text {. N. Semyenov, a Russian engineer, drilled a well to } 21 \mathrm{~m} \text { at Bibi-Heybat on the Ab- } \\
\text { sheron peninsular, Azerbaijan. }\end{array}$ \\
\hline 16 & $\begin{array}{l}\text { The first US oil was drilled (not dug) by Edwin Drake, using a steam engine to reach a total depth } \\
\text { of } 21 \mathrm{~m} \text { at Oil Creek (also named for its natural oil seep), near Titusville, Pennsylvania in } 1859 \text {. } \\
\end{array}$ \\
\hline 17 & $\begin{array}{l}\text { Seeing the futility of gathering oil from surface seeps or trying to mine it from excavated shafts, } \\
\text { Drake studied the techniques of drilling salt wells and decided to bore for the oil. He began drill- } \\
\text { ing in May } 1858 \text { and almost immediately found it impossible to maintain a borehole in the loose } \\
\text { rock and soil just below the surface. He solved the problem by driving sections of pipe into the } \\
\text { ground until bedrock was struck, and from there the drilling continued until the top of an oil de- } \\
\text { posit was reached at a depth of } 69 \text { feet (21 metres) on August } 27,1859 \text {. [17] }\end{array}$ \\
\hline 18 & $\begin{array}{l}\text { Today's exploration and production industry was born on August } 27,1859 \text {, near Titusville when a } \\
\text { well specifically drilled for oil found it. }\end{array}$ \\
\hline
\end{tabular}

The next stage involved lexical and grammatical analysis of the data from Table 1 and selection of facts that later formed the basis of the text. Selection of the material was conditioned by teaching and methodical aims as the developed course was intended for oil and gas professionals with command of English at A2/B1 level who 
wished to activate their communication skills using specialized language resources, so the main task of the first historic module was to revise some grammar structures (Present Perfect, Past Simple, Past Continuous, Past Perfect) and to learn some basic professional terms within an interesting historical context.

Basic terms are vocabulary items that describe notions and action fundamental to the oil production process [18]. As any terminological system, the oil and gas terminological system is inhomogeneous and includes different groups of vocabulary items. Therefore, while determining the basic set of terms for the first module of the online course, the authors turned to different lexical sets. As a result, the following were pointed out as the most important:

- Key (core) industry terms

- Professional industrial terms describing the process of oil production

- Loan terms from adjacent areas (geology) important for understanding of the oil production process

The terms of these lexical sets had to be presented in the text in order to provide its training value according to the aims of the online course. A suggested list is shown in Table 2.

Table 2. Basic Vocabulary

\begin{tabular}{|l|l|l|}
\hline \multicolumn{1}{|c|}{ Key (core) terms } & \multicolumn{1}{|c|}{ Professional industrial terms } & Interindustry terms \\
\hline Oil & Oil well / borehole & Oil field \\
Naphtha & Drilling / to drill / to bore & Oil deposit \\
Petroleum & Recovery of crude oil & Oil seep \\
Crude oil & Drill-bit / pipeline & Rock \\
Bitumen & To mine / to gather / gathering of oil & Bedrock \\
Natural gas & To extract / oil extraction \\
& To transport / transportation of crude oil to distill & \\
\hline
\end{tabular}

In accordance with lexical and grammatical aims, the authors of the article analyzed the selected material from Table 1 and picked the facts that matched the following criteria:

- It is an interesting or a little-known historic fact

- The material contains the selected vocabulary items

- The fact can be rendered using the previously studied grammar structures

It is also important that all history facts were presented chronologically and together formed a complete fragment of the history of oil and gas industry from its onset to boom caused by creation and successful exploitation of oil well drilling technology.

The third and final stage was about proper shaping of the text using different information elements. Here is the result of the work done: 


\subsection{The First Steps in the Oil Industry}

To understand how the oil and gas industry works, it is also important to know how it has changed over time. Small surface occurrences of petroleum in the form of natural gas and oil seeps have been known from early times. Liquid oil was first used as a medicine by the ancient Egyptians. The Assyrians used bitumen as a means of punishment by pouring it over the heads of lawbreakers. The Arabs and Persians distilled crude oil to obtain flammable products for military purposes.

The earliest oil wells were drilled in China around 347AD, with depths of up to $240 \mathrm{~m}$. The drilling was very simple, with basic drill-bits attached to bamboo poles. Back then, oil was burned to evaporate brine to produce the most important ancient commodity of all: salt. Chinese drilling continued until the 10th century, by which time extensive bamboo pipelines connected oil wells with salt springs.

In the 10th century, al-Mas'udi, an Arabic geographer, observing oil seeps in the Absheron peninsular, Azerbaijan, called this place bilad al-naffata (the land of the naphtha fountain). At that time more than 15,000 people were living in and around Baku. Almost of all of them were involved in oil extraction and its transportation by ship, cart, or camel. Extraction methods in those times were extremely primitive mainly hand dug wells at natural seep locations taken to a very shallow depth. Local people $d u g$ oil wells, scooped the thick black liquid out with leather buckets and filled wineskins with it. Then, together with other goods carried by caravans, they brought it to Persia, Mesopotamia and India.

In Russia, the first written mention of the oil gathering appeared in the 16th century. Travelers described how tribes living along the banks of the river Ukhta gathered oil from the surface of the river and used it as a medicine and a lubricant.

The first oil well in the world was drilled (not dug) in Baku in 1848 at BibiHeybatoil field under the direction and initiation of Russian engineer F.N. Semenov. It had happened more than a decade before the drilling of the first well in the US.

In 1859 came the birth of the first oil well in the United States. The Seneca Rock Oil Company contracted a man named Edwin L. Drake to drill in a local oil seep. Seeing the futility of gathering oil from surface seeps or trying to mine it from excavated shafts, Drake studied the techniques of drilling salt wells and decided to bore for the oil. He began drilling in May 1858 and almost immediately found it impossible to maintain a borehole in the loose rock and soil just below the surface. He solved the problem by driving sections of pipe into the ground until bedrock was struck, and from there the drilling continued until the top of an oil deposit was reached at a depth of 69 feet (21 metres) on August 27, 1859. The completion of the well-established the groundwork for the modern petroleum industry, because Drake had shown that oil could be found by drilling for it.

The suggested text is characterized by:

- A variety of basic professional terms

- All grammatical structures studied in this module

- Various facts from early history of the oil and gas industry

- Meaningfulness 
Lexically, the text provides the reader with basic professional terminology of the oil and gas industry. It features:

- Key petroleum terms pertaining to names of oil and products of its processing. petroleum, bitumen, naphtha, crude oil, liquid oil;

- Professional industrial terms for objects and activities to describe the process of oil production and refining. oil well, drill-bit, pipeline, section of pipe, excavated shaft, bore hole, completion of well, to dig, to gather, to drill, to bore, to extract (extraction), to mine, to distill, to evaporate, to produce, to transport (transportation);

- Interindustry terminology borrowed from adjacent sciences, in this case from geology: oil seep, surface seep, oil field, oil deposit, bedrock, loose rock, soil.

- From the point of view of grammar saturation, the textual material enables learners to repeat and show examples of the following verb tenses in a professional text:

- The verb 'to be' in Past Simple;

- Regular and irregular verbs in Past Simple;

- Tenses Present Perfect and Past Simple, Past Simple and Past Continuous, Past Simple and Past Perfect.

With a variety of historical facts in the text and its meaningfulness learners get a detailed picture of the use of petroleum products in the ancient times and the ways of oil production until mid XIX century when this process achieved industrial scale and started to lead the economies of the world powers.

\section{Conclusion}

The overview of the modern e-learning industry in general and the analysis of the most popular platforms for online courses help to formulate requirements to professionally oriented language learning curricula and to functions of e-platforms for creation and delivery of online courses. While developing the online course curriculum:

- Aims of the online course were outlined

- Modules plan was developed

- Texts and audio/video materials were thoroughly selected

- Activities were created

- A set of progress and achievement tests was developed

The analysis of similar online courses curricula resulted in selection of principles for development of texts, which considerably increased the efficiency of online learning. It was decided to follow five criteria for creating texts for online courses.

First, text content of a professionally oriented online course should be developed within the framework of the selected topic.

Second, it should be interesting for this audience.

Third, it should correspond to learners' level of English (in this case, A2/B1). 
Fourth, texts should have all grammar structures selected by the authors for revision and drilling.

And finally, fifth, it should contain vocabulary items on the subject according to educational aims of an online course.

The development of such text content was done by organizing the workflow in three stages:

- A Methodical stage (The aim was to set tasks of drilling appropriate grammar structures and vocabulary items for learners to successfully go through the first module of the online course);

- An Analytical stage (It focused on the analysis of Russian and foreign Internet sources and making a list of historic facts of oil and gas industry development);

- A Creative stage (It was about selecting some facts from the list, editing them and creating a text that would meet all the aforementioned criteria).

Thus, the authors are convinced that the suggested approach to text content development for professionally oriented online courses is likely to be successful and useful.

\section{$5 \quad$ References}

[1] "Promises and pitfalls of online education". 2017-06-09.

[2] https://www.petersons.com/articles/online-degrees/online-education-history

[3] Mayer, R. E.; R. Moreno. A Cognitive Theory of Multimedia Learning: Implications for Design Principles (1998). Checked on March 1, 2010. Archived April 18, 2012.

[4] Moreno, R., \& Mayer, R. (1999). "Cognitive principles of multimedia learning: The role of modality and contiguity". Journal of Educational Psychology. 91:358-368. https://doi. org/10.1037//0022-0663.91.2.358

[5] Johnson, Henry M (2007). "Dialogue and the construction of knowledge in e-learning: Exploring learners' perceptions of their learning while using Blackboard's asynchronous discussion board". European Journal of Open, Distance and E-Learning. 10 (1). Retrieved 2013-10-22.

[6] Trentin G. (2010). Networked Collaborative Learning: social interaction and active learning, Woodhead/Chandos Publishing Limited, Cambridge, UK, ISBN 978-1-84334-501-5

[7] Geng, F. (2014). Confusing terminologies: \#e-learning, learning technologist, educational technologist, discussed by @_A_L_T members. Oxford, UK. https://blogs.it.ox.ac.uk/fawei/ 2014/07/29/confusing-terminologies-e-learning-learning-technologist-educational-techno logistdiscussed-by-a 1_t-members/ https://doi.org/10.1080/1355800750120510

[8] https://elearningindustry.com/elearning-platforms-use-online-courses-10

[9] Fedorova I.A. Principles of text selection for forming of communicative conpetences in learners of technical universities for learning foreign languages/ Collection of reports. Issue \#8. - Moscow: Pero, 2016. C. 394-402.

[10] Bolsunovskaya, L., (2016). Approaches to Genre Analysis of English Engineering Discourse. Vestnik Rossiiskogo Universiteta Druzhby Narodov-Seriya Lingvistica-Russian Journal of Linguistics, 20(1), 25-32.

[11] Sishchuk Yu.M. German borrowings in russian mining-and-geological terminology. Zapiski Gornogo instituta. 2016. Vol.219, p.504-507. DOI 10.18454/PMI.2016.3.504.

[12] https://www.roseassoc.com/a-brief-history-of-the-oil-industry/ 
[13] https://www.britannica.com/science/petroleum

[14] https://dailyreckoning.com/10-amazing-facts-about-oil/

[15] https://grandemotte.wordpress.com/peak-oil-4-exploration-history/

[16] https://infopedia.su/16xb72e.html

[17] https://www.britannica.com/biography/Edwin-Laurentine-Drake

[18] Galich G.G., Klyoster A.M. Cognitive and pragmatic interpretation of terminological fragments in the professional discourse. Advances in Intelligent Systems and Computing. 2018. Vol. 677. P. 242-249. https://doi.org/10.1007/978-3-319-67843-6 29

\section{Authors}

Yuliya Murzo is a Senior Teacher of the Department of Foreign Languages of Saint-Petersburg Mining University, 2, 21st Line, 199106, Saint-Petersburg, Russia.

Svetlana Sveshnikova is an Associate Professor of the Department of Foreign Languages of Saint-Petersburg Mining University, 2, 21st Line, 199106, SaintPetersburg, Russia. (E-Mail: sasveshnikova@yandex.ru)

Natalia Chuvileva is an Associate Professor of the Department of Foreign Languages of Saint-Petersburg Mining University, 2, 21st Line, 199106, Saint-Petersburg, Russia. (E-Mail: chuvileva.n@,mail.ru)

Article submitted 2019-04-27. Resubmitted 2019-06-04. Final acceptance 2019-06-21. Final version published as submitted by the authors. 